\title{
BELT AND ROAD INITIATIVE (BRI) IN ISLAMIC ECONOMICS DISTRIBUTION PERSPECTIVE
}

\author{
Efni Anita \\ Islamic State University of Sulthan Thaha Saifuddin Jambi \\ e-mail: efniraffa@gmail.com \\ EjaArmazHardi* \\ Islamic State University of Sulthan Thaha Saifuddin Jambi \\ e-mail: eja.armaz.hardi@uinjambi.ac.id \\ *Correspondent Author
}

\begin{abstract}
This article aims to analyse Indonesia's policy of joining China's Belt and Road Initiative (BRI) through a perspective of distribution in Islamic economics. The BRI project is one of the agendas of the Chinese government to expand economic hegemony in the international market. At the same time, the Indonesian government has a national development priority program (PSN). However, the state's finite financial condition and the stagnation of economic growth became an obstacle for the Indonesian government to realize the domestic infrastructure projects. Therefore, the Indonesian government requires a source of capital other than the state budget. One of the steps taken by the Indonesian government is to become part of BRI. Behalf of these difficulties and opportunities, how Islamic economics argue the Indonesian government policy especially on distribution perspective. To address the question, this article utilizes descriptive qualitative methods and the theory of distribution of Islamic economics. It was found that the Indonesian government's infrastructure policy is in line with the spirit of Islamic distribution to reduce income disparity by providing equal access to infrastructure for the communities. Beside BRI's open access and integration to regional countries and supported by the needs of China's domestic industrial raw materials, Indonesia is predicted to be the largest exporter of raw materials. The need to export these raw materials will also tend to be exploitative and contrary to Islamic principles. Therefore, to tackle that, this article recommends the formulation of policies that encourage an expansive domestic industry so that Indonesia is not only an exporter of raw materials but also an exporter of goods and services.
\end{abstract}

Keywords: Belt and Road Initiative, Government Policy, Distribution, Islamic Economics. 


\begin{abstract}
Abstrak
Artikel ini bertujuan untuk menganalisis kebijakan bergabungnya Indonesia dengan gagasan Belt and Road Initiative (BRI) China ditinjau melalui perspektif distribusi dalam paradigma ekonomi Islam. Proyek BRI merupakan agenda pemerintah China untuk memperluas hegemoni ekonomi di pasar Internasional. Disaat bersamaan pemerintah Indonesia memiliki program prioritas pembangunan nasional. Akan tetapi kondisi keuangan negara yang difisit and stagnansi pertumbuhan ekonomi menjadi kendala pemerintah Indonesia untuk mewujudkan proyek infrastruktur dalam negeri tersebut. Oleh karena itu, pemerintah Indonesia membutuhkan sumber modal selain dari APBN. Salah satu langkah yang ditempuh oleh pemerintah Indonesia adalah menjadi bagian dari BRI. Artikel ini memanfaatkan metode kualitatif deskriptif and teori distribusi ekonomi Islam. Ditemukan bahwa kebijakan infrastruktur pemerintah Indonesia sejalan dengan spirit distribusi Islam untuk mengurangi disparitas pendapatan melalui menyediakan pemerataan akses infrastruktur bagi masyarakat. Kemudian, keterbukaan akses and integrasi BRI pada negara kawasan and didukung oleh kebutuhan bahan baku industri domestik China, Indonesia diprediksi akan menjadi negara eksportir bahan baku terbesar. Kebutuhan ekspor bahan baku tersebut juga akan cenderung eksploitatif and bertentangan dengan prinsip Islam. Oleh karena itu, artkel ini merekomendasikan perumusan kebijakan yang mendorong industri dalam negeri yang ekspansif agar Indonesia tidak hanya menjadi ekportir bahan baku mentah akan tetapi juga ekportir barang and jasa.
\end{abstract}

Kata Kunci: Belt and Road Initiative, Kebijakan, Infrastruktur, Distribusi, Ekonomi Islam

\title{
INTRODUCTION
}

In the last few decades, poverty and unemployment have become important issues that have always been the concern of the Indonesian government. According to data released by the Indonesian Central Statistics Agency (BPS), the number of poor people in Indonesia has decreased every year, it can be seen that as of March 2018 the percentage of poverty in Indonesia reached 9.82 percent or as many as 25.95 million people (Badan Pusat Statistik 2018b). In addition, the number of open unemployment per February 2019 reached 5.01 percent, this percentage decreased from the same period in February 2016 which was 5.50 percent (Badan Pusat Statistik 2019). The decline in the percentage of poverty and open unemployment was accompanied by the growth of the Human Development Index (HDI) in Indonesia, as of 2018 Indonesia's HDI was at 71.39 percent, this percentage increased by 4.86 percent from 2010 with the HDI percentage of 66.53 percent (Badan Pusat Statistik 2018a).

The reduction in the percentage of poverty and unemployment cannot be separated from the role of the Indonesian government in accelerating the issuance of policies aimed at accelerating economic growth, equitable access, and creating comprehensive social welfare. One of the government policies used to achieve these goals is to accelerate the realization of infrastructure policies. This policy is contained in the 2015-2019 National Medium Term Development Plan (RPJM). According to the report document of the Committee for the Acceleration of Proiritas Infrastructure Provision (KPPIP) which was formed by Presidential Decree No. 75 of 2014 and renewed by the issuance of Presidential Decree No. 122 of 2016 states that the Indonesian government has 30 priority projects that are divided into 7 strategic sectors 
(Prioritas 2018). The national project is estimated to require an investment of up to $\mathrm{Rp}$ 2,428,146 Trillion.

The estimated cost in the National Strategic Project (PSN) is the largest in the energy sector which reached Rp 1,888,528 trillion, which was derived into 7 projects. Whereas PSN which has the lowest budget is the telecommunications sector for the procurement of Palapa Ringroad Broadband worth Rp 5,840 Trillion. For Road and Bridge Infrastructure, and Transportation expenditures are in the range of IDR 267.40 Trillion and IDR 256.50 Trillion (see Table 01). At the same time, the state revenue according to the 2018 State Budget (APBN) only reached the range of IDR 1,894.7 trillion, while government spending reached IDR 2,220.7 trillion, so that Indonesia experienced a budget deficit of IDR 326 trillion. Based on these data, it can be seen that the total estimated budget for the realization of PSN is much larger than Indonesia's state revenue which is only in the range of IDR 1,894.7 trillion, so that PSN is not funded through the APBN which comes from taxes, PNBP, excise and grants. Thus to accelerate the realization of PSN the Indonesian government is seeking various expansive schemes and policies as an alternative funding. Among the schemes used by the Indonesian government is to form a Project Development Fund (PDF) in collaboration with international institutions. Derivation of the scheme is such as assigning a State-Owned Enterprise (BUMN) to run a PSN, a Government Cooperation Agency (PPP) scheme and a foreign loan.

Table 01

List of Indonesia's Priority Projects Medium Term Development Plan (RPJM) 2015-2019

\begin{tabular}{clc}
\hline No & \multicolumn{1}{c}{ Sectors } & IDR (Trillion) \\
\hline $\mathbf{1}$ & Roads and Bridges & 267,40 \\
$\mathbf{2}$ & Transportations & 256,50 \\
$\mathbf{3}$ & Telecommunications & 5,84 \\
$\mathbf{4}$ & Electricity & 612,02 \\
$\mathbf{5}$ & Energies & $1.188,53$ \\
$\mathbf{6}$ & Water Resources and Sanitation & 76,93 \\
$\mathbf{7}$ & Waste Origin Energy & 19,75 \\
& Total & $2.426,96$ \\
\hline
\end{tabular}

Source: KPPIP Report 2018 (Prioritas 2018)

Although Indonesia's foreign debt originates from several countries and international institutions, in recent years Indonesia has made exponential expansion in terms of PSN cooperation and its funding scheme with China. This can be seen from the increasing portion of debt and the number of projects handled and financed by China. Both parties have signed a Momerandum of Understanding (MoU) represented by various parties from Indonesia and China to work on around 23 PSNs from 37 (instead of 30) projects issued by Indonesia on April 25-27 2019(Adhi Bagaskara 2019). The investment value of the seven strategic government projects has reached USD91.1 billion or Rp1,275.4 trillion. Then, the scheme carried out by both parties is a business to business ( $\mathrm{B}$ to $\mathrm{B}$ ) scheme. The expansion of cooperation and project funding undertaken by China with several countries cannot be separated from the Chinese government's grand program known as the Belt and Road Initiative (BRI).

Indonesia is one of the developing countries that joined the BRI China project. This cannot be separated from the budget deficit experienced by Indonesia in the last 
few years. In addition, the broad demographic and geographic heterogeneity poses a big challenge for Indonesia to ensure the even distribution of impact of the BRI project runs well. Equitable distribution, both labor or economic impact, is the key to the success of PSN in Indonesia, because in distribution there is justice that must be fought for to achieve national welfare. In the perspective of Islamic economics, the distribution system becomes one of the absolute requirements and a state economic system to ensure economic equality in society. As is well known that equity is not only related to the economy, but also directly to the social aspect. Accommodation of these two aspects of justice is found in the Islamic economic system which is reflected in the zakat system as a form of Islamic social solidarity(Ayub 2007; Qarad \}a>wi> (al) 1973). Therefore, it is interesting to see PSN in the framework of justice distribution in the perspective of the Islamic economy, because PSN funding through debt provides two possible implications, namely negative or positive for a country's social economic equality.

Based on the author's investigation, there are many studies that discuss the impact of the involvement of developing countries in the BRI project. Among these studies, concerns were found about the potential negative consequences for developing countries' domestic economies if China began to export iron excessively(Huang 2016). This is because China's production has seen capacity, so China needs new areas as a market, therefore the BRI policy is considered more as an effort to survive the weakening Chinese economy.(Wang 2016). From the aspect of debt sustainability, it was found that Sri Lanka was unable to pay interest of 6 percent of the total debt of USD8 billion for the construction of port infrastructure, so that in July 2017 China agreed to a dept-to-equity swap with port management consequences for up to 99 years(Hurley, Morris, and Portelance 2018).Unlike the negative findings of the previous BRI project, (Herrero and Xu 2017)concluded that the land silk lane and maritime silk lane at least had an effect on global trade from the aspect of reducing the cost of transportation between BRI member countries. It was then stated that infrastructure development through BRI could increase economic growth (African countries) and the transfer of industrial labor-incentives to Africa(Chen 2016). According to (Rahman 2019) said that on the legal jurisprudence perspective the Indonesian government decision to join the BRI is permitted as long as the contract is not contented by illegal transaction in Islamic view.

Different from the previous studies, this article focuses on the economic equality's implication of Indonesian policy,which joined and put the Belt and Road Initiative (BRI) on the National Strategic Plan (PSN). This article argues that Indonesia's policy of joining the BRI and PSN projects, which are majority funded by foreign debt from China, is interesting to look at from the concept of Islamic distribution. This is due to the purpose of a government policy is the equitable distribution of economic and social access so as to create public welfare as a whole. It further argues the distribution equality either capital or employment has tended to bring the great implication for both country's economy, as well as the inequality might gave the several disadvantages for Indonesia people and economic matter. To arrive these arguments, this article attempted the qualitative research which utilized the content analysis, as well as this article has been assisted by the Islamic economics distribution perspective. Furthermore, this article is divided into sub-topics of discussion;following the introduction will be discussed about the direction of Indonesian government policy. The next section of this article presented the BRI program. Before the conclusion this 
article talked about the economic distribution in Islamic economics perspective, as well as its implication on poverty and employment distribution also will be presented.

\section{LITERATURE REVIEW \\ Belt and Road Initiative (BRI)}

President Xi Jinping introduced the vision of the Silk Road Economy in an agenda of his visit to Kazakhstan at Nazarbayev University on September 7, 2013, and the concept of the New Maritime Silk Road was announced during his visit to Indonesia before the parliament on 3 October 2013. The two concepts are known as One Belt One Road (OBOR). ), and became known as the Belt and Road Initiative (BRI)(Du and Zhang 2018). BRI is on the Chinese government's big agenda in efforts to integrate the economy between China and Asia, Europe and Africa. This integration is carried out with an emphasis on the transformation of the Chinese economy against the backdrop of structural transformation and excess domestic production. Therefore, China needs to expand its companies into the global economy(Du and Zhang 2018).

BRI's initiation is not limited to Free Trade Management (FTA), but it is a comprehensive infrastructure initiative that leads to the design of economic integration. The BRI Blueprint states that the countries involved in BRI are jointly developing ports, roads, airports, railroads, and others. Besides being the main donor in infrastructure development, China is building support facilities such as the Silk Road Fund (SRF), the Asia Intrastructure Investment Bank (AIIB), China's Foreign Assistance, and global business entities(Du and Zhang 2018).

In addition, BRI can also be seen as an effort to promote national economic development by expanding exports, increasing access to natural resources, and providing essential materials for the domestic industry(Du and Zhang 2018). In this position, as the owner of extensive tropical forests, abunandt natural resources and fertile land can increase the export of raw materials. Besides that, if the raw material is exponentially transported abroad, and at the same time the domestic industry does not experience an increase it tends to erode foreign exchange and the nominal gap of Indonesian exports and imports.

Based on industry statistics, the development of Indonesia's exports as of 2016 the role of the oil and gas sector is only 9.07 percent and the non-oil and gas sector reaches 90.93 percent of Indonesia's total exports. The non-oil and gas sector which has the biggest role is the processing industry at 75.99 percent(Kemenprin 2018). In addition, 7 export commodities consist of rubber, textiles, palm oil, cocoa, coffee, electronic goods, and forest product production (N 2018). Indonesia's decision to join the Belt and Road Initiation (BRI) initiated by China allows Indonesia to become the largest exporter of raw materials in China's domestic industry. Therefore, this policy must be accompanied by growth in the domestic industry. This is because the flow of global trade after the completion of the BRI project will accelerate. In addition, the resilience of the domestic industry can support economic growth so that concerns over the ability to pay loan interest from infrastructure development supporting BRI projects can be put aside.

This grand project of Chinese ideas only has an economic dimension, but is multi-dimensional in various aspects. The idea that invites regional countries involved in BRI with a strategy of sharing roles (division of labor) aims to maintain and improve regional stability(Kurniawan 2016). In addition, because BRI is involved in various Asian, African and European countries, it is stated that when the BRI project runs, 
China not only benefits economically but can also change the world goepolitic constellation that makes China a major new world power (Ramadhan 2018).

\section{Indonesia's National Strategic Policy}

The Indonesian Government's macro policies are contained in the 2015-2019 Medium-Term Development Plan (RPJM) which prioritizes equitable national access. In order to accelerate equal access to this, the Government of Indonesia has prepared a National Strategic Project (PSN). The leading sectors as stated in the 2015-2019 RPJM are divided into several sectors, namely first, food sovereignty by increasing the production of domestic staples and irrigation. Second, energy sovereignty includes increasing energy resources, domestic use, construction of FSRUs, gas pipelines, SPBGs, city gas networks, and refineries. Third, maritime affairs, including strengthening maritime national identity, eradicating illegal fisheries, building national connectivity, and developing maritime and marine economies. Fourth, the tourism and manufacturing sectors. Fifth, basic infrastructure water resistance and connectivity, and sixth, the environmental sector(Republik Indonesia 2015).

Later developments, the leading sector policy underwent a change, so the government restructured PSN. Due to various obstacles in implementing these projects related to law, funding, projects not accepted by the market, licensing and land acquisition, a Committee for the Acceleration of Priority Infrastructure Provision (KPPIP) was formed in 2014 through Presidential Regulation (Perpres) Number. 75 of 2014 and updated its legal basis through Presidential Decree No. 122 of 2017. KPPIP aims to guard infrastructure projects which are specifically stipulated by the Coordinating Minister for Economic Affairs No. 12 of 2015 j.o Coordinating Minister for Economy No. 3 of 2017 in the list of priority projects (Prioritas 2018). In the 2018 KPPIP report document, there are at least 37 PSNs divided into 7 sectors.

One of the implications of this policy is that according to the report of The Global Competitiveness Index 4.0 2018 Rankings, Indonesia is ranked 45th out of 140 countries in the world with a score of 64.9, this ranking has increased 2 levels from the previous year. Meanwhile, at the ASEAN level, Indonesia ranks 4th after Singapore, Malaysia and Thailand. Then from the measured index, macroeconomic stability got the highest score, namely 90, while the lowest score was innovation capacity with a value of 37 on a scale of $0-100$. The average score for Indonesia's infrastructure ranks 71/140 with a value of 66.8, while the highest score is on airport connectivity, while the lowest score is the availability of railway lines $(6.1 / 82)$ and the road connection index score is 34.6, which is ranked 120 (Schwab 2018).

With the low score in the aspect of road infrastructure connectivity, the government has formulated several policies related to the acceleration of Toll road development. Some of these conveniences include the rules and regulations that support the acceleration of Toll road construction, the establishment of a Toll Road Regulatory Body (BPJT) as a Toll road regulator, the establishment of KPPIP under the Coordinating Minister for the Economy, bankable and investor friendly Toll road arrangements, Toll tariff adjustments, and risk management land acquisition with a revolving fund mechanism through the Public Service Agency (BLU)-BPJT and Land Capping (BPJT 2018). With this convenience, it is hoped that it can provide a new flow of investment climate in Indonesia, so that it can attract domestic investors, donor agencies, and other countries. In addition, the amount of loans from abroad, both 
government and private, reached IDR 5,277 trillion or USD 360.53 billion as of October 2018.

\section{Distribution in Islamic Economics}

The policy of a country is closely related to reducing the gap between rich and poor is distribution. The policy steps taken by the Indonesian government with all its efforts are a noble goal for equitable distribution which includes income, maternity, resources, and so on. Therefore distribution becomes an important part that must be considered by the state.

Islam as a holistic religion has special attention regarding distribution. In addition to the instruments of Zakat, Infaq, Almsgiving and Islamic Waqf, the interpretation of distribution in various aspects must be based on justice. Yusuf Qaradawi stated that the transmission of Islam in the context of wealth distribution is a social responsibility (al-takaful al-'ijtima'i) Muslims to others (Yusuf al-Qardhawi 1973). According to Baqr As-sadr, the implementation of social responsibility is that the state is allowed to carry out and regulate economic activities without exception such as managing natural resources and allowing limited private ownership. Meanwhile, Abdul Manan is of the view that operational policies must have a long-term orientation to reduce the income gap and private ownership must be based on moral, religious, community obligations and not make exploitation(Mannan 1993). Then this view is carried out with Natural Resources (SDA) which are controlled and managed by the state with strong control in order to increase the growth of Micro, Small and Medium Enterprises (MSMEs) and avoid excessive exploitation of natural resources(Sulistiani 2017).

The equality of Islamic distribution is the best way in providing the state welfare. To this, the distribution in Islamic perspective clearly to assist the poverty alleviation through fulfilling the basic needs (Mulyany and Furqani 2019). On the one hand the distributive model in Islamic teaching has been rooted in the Al-Quran and Hadith Muhammad SAW that become the based on Muslim economic activities (Rahim and Mohammed 2018). Furthermore, the circle of economic Islamic activities not only influenced the human habits but also correlated to the Islamic compliance of the Islamic teaching. As a result, the justice distribution has been played an important role in Islamic country decision (Emamzadeh 2020). In spite of it, the distribution enabled to be used as a tool in reducing the economic gap among society (Hasan 2020). As the consequences the implementation the justice distribution either the capital or employment in the Belt and Road Initiative (BRI) through Memorandum of Understanding (MoU) between China and Indonesian Government is important.

\section{METHOD}

This article uses a type of qualitative research that makes use of library research. In exploring the objectives of this article, the literature study was conducted using descriptive analysis. The data used in this article are secondary data issued by the authorities in reporting data. Besides using secondary data, this article also refers to relevant literature in accorandce with the topic being discussed. Then from the data and literature references this article carries out a theoretical dialogue on the topics and objectives being discussed, so that it can come up with conclusions that are in accorandce with the objectives of writing this article. 


\section{RESULTS AND DISCUSSION \\ Infrastructure Funding Scheme}

Based on the KPPIP report led directly by the Coordinating Minister for the Economy, the government has implemented various funding schemes to finance infrastructure development. In accumulation, the total investment value needed in order to accelerate the realization of infrastructure reaches IDR 2,428.146 trillion. With the condition of the State Budget and Revenue (APBN) experiencing a deficit, it seems unlikely that the Indonesian government will self-finance the infrastructure acceleration. In order to accelerate this, the government has implemented several steps to attract investors to invest. Among the things that are being done globally is to revise the Presidential Regulation (Perpres) No. 56 of 2017 concerning the handling of social impacts in the context of land acquisition. The revised Perpres aims to expand the scope of projects and develop forms of compensation for land acquisition and reduce community resistance. Therefore, the government issued Perpres no. 62 of 2018 challenges the handling of social impacts in the context of providing land for public interests.

Then, the government issued the 16th Economic Policy Package (PKE), which in essence was: One, the expansion of corporate income tax reduction facilities, in short that term was to expand the provision of Tax Holiday. Second, is relaxation of the Negative Investment List (DNI). The government wants greater investment, both domestically, including foreign investment (PMA). Third, the regulation of foreign exchange proceeds from exports for Natural Resources(Humas Sekretariat Kabinet 2018). The 16th PKE will have a long-term impact but not in the short term, this is because the tax holiday is valid for an investment of 5 to 20 years. In addition, the government issued Presidential Decree no. 55 of 2018 concerning the Transportation Master Plan (RIT) for Jakarta, Bogor, Depok, Tangerang, and Bekasi which are areas with rapid development.

Furthermore, the government also issued a Presidential Decree on the assignment of Pelindo I through Presidential Regulation no. 81 of 2018 concerning the acceleration of the development and operation of the port and industrial area of Kuala Tanjung in North Sumatra. This was done after KPPIP analyzed the Outline Business Case (OBC) of the International Relations Port (PHI) and provided input that the industrial estate must have an institution / agency acting as a master developer to attract investors (Prioritas 2018). Thus, PT. Pelindo I signed a Memorandum of Understanding with Kemenprin and Kemenhub which agreed on the development of the landlord scheme.

Besides the revision and issuance of the Presidential Decree, the Indonesian government is also developing a Viability Gap Fund (VGF) for the Public Private Partnership (PPP) project. The VGF provided to the PPP aims to support financial leverage in running the project, as well as allow private parties to be involved in funding. Besides PPP, the government is also developing a Project Development Fund (PDF). PDF is a facility provided by the Ministry of Finance to assist the Person in Charge for Cooperation Projects (PJPK) in preparing pre-feasibility studies, preparing tender documents, and assisting PJPK in the PPP transaction process until financial close (Prioritas 2018).

On the other hand, due to inaccurate, non-uniform map data, and overlapping permits resulting in border conflicts, the government implemented the One Map Policy (KSP). This policy is expected that development planning and decision-making will be 
based on spatial data. The seriousness of this KSP was shown by the launching of Geoportal 83 out of 85 thematic maps of Ministries/Institutions and Local Governments that had gone through a process of complications and integration (Prioritas 2018). Furthermore, the government also developed Limited Management Rights (HPT) or Limited Concession Scheme (LCS) and other financial instruments such as: forex hedging/domestic currency risk including Call Spread Options and Domestic NonDeliverable Forward; Limited Mutual Funds (RDPT); Infrastructure Investment Fund (DINFRA); Asset-Backed Securitization (KIK EBA); Real Estate Investment Fund (REIT); Global Bond (Komodo Bond); Perpetual Bond; Manicipal Bond; Green Bond, and; Assistance for Waste Management Services Costs (BLPS). Of the several schemes mentioned above are implemented in the National Strategic Project (PSN) in detail as shown in the Table 02:

Table 02

Indonesia's National Strategic Projects as of 2018

\begin{tabular}{|c|c|c|c|c|}
\hline No & Priority Projects & $\begin{array}{c}\text { Value } \\
\text { (Trillion) }\end{array}$ & Scheme & Location \\
\hline $\mathbf{A}$ & Road and Bridge Sector Priority Project $(268,5$ & $86 \mathrm{~T})$ & & \\
\hline 1 & Toll Serang - Panimbang & 1,191 & KPBU & Central Java \\
\hline 2 & Toll Manado - Bitung & 5,120 & KPBU & North Sulawesi \\
\hline 3 & Toll Balikpapan - Samarinda & 9,970 & KPBU & East Kalimantan \\
\hline $4 \mathbf{a}$ & Toll Meand - Binjai & 1,600 & Assignment of BUMN & North Sumatera \\
\hline 4b & Toll Palembang - Indralaya & 3,300 & Assignment of BUMN & South Sumatera \\
\hline $4 c$ & Toll Pekambaru - Dumai & 16,200 & Assignment of BUMN & Riau \\
\hline 4d & Toll Bakauhuni - Terbanggi Besar & 16,700 & Assignment of BUMN & Lampung \\
\hline $4 e \& f$ & $\begin{array}{l}\text { Toll Terbanggi Besar - Pematan Panggang - } \\
\text { Kayu Agung }\end{array}$ & 21,950 & Assignment of BUMN & $\begin{array}{l}\text { Lampung andNorth } \\
\text { Sumatera }\end{array}$ \\
\hline $4 g$ & Toll Palembang - Tanjung Api-Api & 14,200 & Assignment of BUMN & South Sumatera \\
\hline $4 h$ & Toll Kisaran - Tebing Tinggi & 13,454 & Assignment of BUMN & North Sumatera \\
\hline 4i-l & $\begin{array}{l}\text { Toll Binjai - Langsa, Langsa - Lhoksemawe, } \\
\text { Lhoksemawe - Sigli \& Sigli - Banda Aceh }\end{array}$ & 75,318 & Assignment of BUMN & $\begin{array}{l}\text { Riau andWest } \\
\text { Sumatera }\end{array}$ \\
\hline $\begin{array}{c}4 m \& \\
n\end{array}$ & $\begin{array}{l}\text { Toll Pekanbaru - Bangkinang - Payakumbuh - } \\
\text { Bukit Tinggi \& Bukit Tinggi - Padang Panjang } \\
\text { - Lubuk Alung - Padang }\end{array}$ & 36,594 & Assignment of BUMN & $\begin{array}{l}\text { Riau andWest } \\
\text { Sumatera }\end{array}$ \\
\hline 40 & $\begin{array}{l}\text { Toll Tebing Tinggi - Pematang Siantar - Prapat } \\
\text { Tarutung - Sibolga }\end{array}$ & 19,778 & Assignment of BUMN & North Sumatera \\
\hline 5 & Toll Probolinggo - Banyuwangi & 21,072 & KPBU & East Java \\
\hline 6 & Toll Yoyakarta - Bawean & 12,139 & Potensi KPBU & $\begin{array}{l}\text { D.I Yogyakarta } \\
\text { andCentral Java }\end{array}$ \\
\hline B & Transportation Sector Priority Project $(256,49$ & $5 \mathbf{T})$ & & \\
\hline 7 & KA Kaltim & 53,300 & Private & East Kalimantan \\
\hline 8 & KA Makasar - Parepare & 8,250 & APBN and KPBU & South Sulawesi \\
\hline 9 & KA Ekspress Bandara Soekarno - Hatta & 24,500 & KPBU and BUMN & $\begin{array}{l}\text { DKI Jakarta and } \\
\text { Banten }\end{array}$ \\
\hline 10 & MRT Jakarta Jalur Utara - Selatan & 17,000 & $\begin{array}{l}\text { APBN and APBD DKI } \\
\text { Jakarta Foreign Loan }\end{array}$ & DKI Jakarta \\
\hline 11 & LRT Jakarta, Bogor, Depok and Bekasi & 23,000 & Assignment of BUMN & $\begin{array}{l}\text { DKI Jakarta andWest } \\
\text { Java }\end{array}$ \\
\hline 12 & LRT South Sumatera & 12,500 & Assignment of BUMN & South Sumatera \\
\hline 13 & LRT DKI Jakarta & 7,345 & Penugasan BUMD & DKI Jakarta \\
\hline 14 & Pel Hub Internasional Kuala Tanjung & 30,000 & $\begin{array}{l}\text { Potential of BUMN } \\
\text { Assignment }\end{array}$ & North Sumatera \\
\hline 15 & Pel Hub Internasional Bitung & 34,000 & Potential KPBU & North Sulawesi \\
\hline 16 & Pel Patimban & 43,200 & $\begin{array}{l}\text { APBN and Foreign Loan, } \\
\text { APBD andPrivate }\end{array}$ & West Java \\
\hline 17 & Inland Waterways Cikarang - Bekasi - Laut & 3,400 & KPBU & $\begin{array}{l}\text { DKI Jakarta andWest } \\
\text { Java }\end{array}$ \\
\hline $\mathbf{C}$ & Telecommunication Sector Priority Project (5, & $340 \mathrm{~T})$ & & \\
\hline 18 & Palapa Ring Broadband & 5,840 & KPBU & All Indonesia \\
\hline D & Electricity Sector Priority Project $(612,020$ T) & & & \\
\hline 19 & PLTU Batang & 40,000 & $\begin{array}{l}\text { KPBU and IPP PT Bhimsena } \\
\text { Power Ind }\end{array}$ & Batang, Central Java \\
\hline 20 & PLTU Indramayu & 27,000 & APBN Foreign Loan & Indramayu \\
\hline 21 & PLTU Mulut Tambang & 210,860 & Assignment of BUMNand & Sumsel, Jambi, Riau, \\
\hline
\end{tabular}




\begin{tabular}{|c|c|c|c|c|}
\hline & & & IPP & Kaltim, Kalteng \\
\hline 22 & PLT Gas & 302,120 & $\begin{array}{l}\text { Assignment of BUMNand } \\
\text { IPP }\end{array}$ & \\
\hline 23 & Central - West Java Line $500 \mathrm{kV}$ & 7,640 & BUMN & $\begin{array}{l}\text { Central JavaandWest } \\
\text { Java }\end{array}$ \\
\hline 24 & Transmisi Sumatera $500 \mathrm{kV}$ & 24,400 & $\begin{array}{l}\text { Assignment of } \\
\text { BUMNandPrivate }\end{array}$ & Pulau Sumatera \\
\hline $\mathbf{E}$ & Energy Sector Priority Project $(1.188,528$ T) & & & \\
\hline 25 & Oil refinery Bontang & 197,580 & $\begin{array}{l}\text { Assignment PT. Pertamina } \\
\text { with cooperation Private }\end{array}$ & East Kalimantan \\
\hline 26 & Oil refinery Tuban & 199,300 & $\begin{array}{l}\text { Assignment PT. Pertamina } \\
\text { with cooperation Private } \\
\text { (Investor: Rosnelf) }\end{array}$ & East Java \\
\hline 27 & Revitalization of ExistingRefinery (RDMP) & 246,220 & Assignment of BUMN & $\begin{array}{l}\text { Cilacap, Jateng, } \\
\text { Balongan, Jabar, } \\
\text { Dumai, Riau, } \\
\text { Balikpapan, Kaltim }\end{array}$ \\
\hline 28 & $\begin{array}{l}\text { Development of the Abadi Field in the Masela } \\
\text { Working Area }\end{array}$ & 289,900 & Private KKS & Maluku \\
\hline 29 & $\begin{array}{l}\text { Field Development Gendalo, Maha, Gehem } \\
\text { and Bangka }\end{array}$ & 124,800 & Private KKS & $\begin{array}{l}\text { Cekungan Kutai, } \\
\text { Kaltim }\end{array}$ \\
\hline 30 & Proyek Tangguh LNG Train 3 & 104,000 & Private KKS & $\begin{array}{l}\text { Teluk Bintuni, West } \\
\text { Papua }\end{array}$ \\
\hline 31 & $\begin{array}{l}\text { Jambaran Gas Unitization Field Development - } \\
\text { Tiung Baru }\end{array}$ & 26,728 & BUMN KKS & Bojonegoro, Jatim \\
\hline $\mathbf{F}$ & \multicolumn{4}{|c|}{ Priority Projects in the Water Resources and Sanitation Sector $(76,931 \mathrm{~T})$} \\
\hline 32 & SPAM Semarang Barat & 1,191 & KPBU & Central Java \\
\hline 33 & SPAM Jatiluhur & 1,670 & KPBU & $\begin{array}{l}\text { West Javaand DKI } \\
\text { Jakarta }\end{array}$ \\
\hline 34 & SPAM Lampung & 1,670 & KPBU & $\begin{array}{l}\text { West Javaand DKI } \\
\text { Jakarta }\end{array}$ \\
\hline 35 & Jakarta Sewerage System & 70,000 & APBN Foreign Loan Jepang & DKI Jakarta \\
\hline 36 & Tanggul Laut Fase A & 2,400 & $\begin{array}{l}\text { APBN, APBD, BUMN, } \\
\text { andPrivate }\end{array}$ & DKI Jakarta \\
\hline $\mathbf{G}$ & Waste Origin Energy Project $(19,746$ T) & & & \\
\hline 37 & Trash Origin Energy of Big Cities & 19,746 & KPBU andPrivate & $\begin{array}{l}\text { DKI Jakarta, } \\
\text { Tangerang, West Java, } \\
\text { Central Java, East } \\
\text { Java, South } \\
\text { Sulawesiand Bali }\end{array}$ \\
\hline & TOTAL & $2.428,146$ & & \\
\hline
\end{tabular}

Source: Annual Report of KPPIP 2018

In general, the policies issued by the Indonesian government regarding ease of investment boil down to how the project attracts local investors and foreign investors to invest in Indonesia. At the same time China is also building a means of supporting the implementation of the Belt and Road Initiative (BRI), one of which is the establishment of the Asia Infrastructure Investment Bank (AIIB). In connection with these two things, the new maritime silk road initiated by China seems to be in line with government policies to strengthen the national maritime sector. As a result, the AIIB would change the economic and political pattern in the Asia (Yu 2017).

On the one hand, Indonesia's state budget deficit is the biggest obstacle to implementing this policy in an expansive and comprehensive manner. Therefore, the AIIB, the result of the idea of China, is an alternative for the government to obtain foreign funding to finance several PSNs(Tinni 2014). This has become one of the factors that led Indonesia to become a member of the AIIB under the Multilateral Development Bank (MDB) between the two countries(Weiss 2017).

\section{BRI and Economic Equity}

The complexity of the Indonesian people is a burden for the government to take policies that are right on target and provide holistic solutions that lead to the welfare of society. As a democratic country, Indonesia in taking policies is required to involve all 
elements of society represented through the House of Representatives (DPR) and the Regional (DPRD). Although later the formulation and implementation of these policies did not fully satisfy the entire community. However, in the formulation of government policy departs from justice and is free from the interests of groups, and personal.

Infrastructure development has been the rising star of the Indonesian government's policies set out in the 2015-2019 National Medium-Term Development Plan (RPJM). Normatively the RPJM leads to participation and social welfare. With this aim, the government infrastructure development policy can be seen from the perspective of economic distribution for poverty alleviation. Chamber states that poverty is an integrated concept: proper; powerless; state of emergency; dependence, and; geographic and/or sociological isolation (Suryawati 2005). The fifth concept is at least in line with the geographical conditions of Indonesia which has more than 1700 islands and is dominated by maritime affairs. It can be understood that the construction of ports, roads and other infrastructure is the government's effort to provide external access for the community to be connected and integrated from one region to another.

In addition, the existence of equitable access that is built has a multiplier effect on people's income and increases the number of workers in general. However, what is of concern is whether people who fall into the category of alienation can access the infrastructure built by the government. From the report released by KPPIP, it is stated that the road infrastructure included in the National Priority Project (PSN) is Toll road construction. Toll roads are Toll roads that are paid for specifically for four-wheeled users, so that at certain points Toll road facilities cannot be directly enjoyed by the poor who do not own four-wheeled vehicles. From the perspective of increasing the income of the poor, the presence of Toll roads cannot be directly felt. However, the impact felt by the community must go through various phases before touching the poor. Thus, the development of Toll road infrastructure by the Indonesian government that aims to provide equitable access to roads for all Indonesian people and reduce the number of isolated people cannot be achieved properly, because at the same time the grassroots community becomes isolated because they cannot directly enjoy the facility.

On the other hand, the development of national strategic infrastructure is mostly financed by cooperation with third parties, either domestic/foreign private individuals or domestic and foreign corporations. This is caused by the state's inability to finance the project itself so that other sources of funding are needed. One of the schemes carried out by the Indonesian government as mentioned above is foreign loans. Recently, Indonesia joined the Belt and Road Initiative (BRI) grand project initiated by China. As of April 2019, the Chinese government signed a Memorandum of Understanding (MoU) with the Indonesian government to take part in financing infrastructure development. Of the 37 PSNs (instead of 30), 23 were approved by the Chinese government to finance. According to the Coordinating Minister for Maritime Affairs, the 23 projects were carried out under the Business to Business (B to B) scheme and the investment value reached USD91.1 billion or Rp1,275.4 trillion.

In the short term, infrastructure development in Indonesia only involves parties who have large capital, such as international institutions, individual investors and so on. For the grass root community in Indonesia, they cannot participate in funding to get a return from the investment due to limited funds. Therefore, in the short term, the effect of infrastructure development cannot be enjoyed directly by the grassroots community, but in the long term the multiplier effects of this development can have an impact on society. Furthermore, equitable distribution of income for the poor from infrastructure 
policies can be achieved in the long term with economic growth (Maryaningsih, Purwanto, and Oktiyanto 2014). Thus the infrastructure development launched by the government with Indonesia's joining the BRI project initiated by China will not have an impact on society in the short term.

The goal of China's BRI, which enters the Indonesian territory, tends to exploit local natural resources. This is motivated by the turmoil over China's domestic production capacity (over production) and at the same time the Chinese industry requires raw materials to produce finished goods. Then the production goods are exported abroad. If this is the case, the grassroots community cannot directly play a role in managing their natural resources.

Furthermore, distribution in Islam aims so that property does not rotate among several groups or groups. Thus Islam prohibits usury because it has an impact on the flow of profits to investors and there is an accumulation of capital in certain groups (Aprianto 2016). As previously explained, priority infrastructure development in Indonesia uses foreign debt based on usury. Therefore, it is difficult for Indonesia in the long run to get out of the foreign debt bondage, the day the principal and interest will increase. As the analysis conducted by Ali Sakti found that in a period of 30 years, Indonesia's debt had increased to 1500 percent of the original principal debt(Ali Sakti 2007). However, the Indonesian government provides assurance that Indonesia's foreign debt financing is still in the safe category and the Indonesian government is diversifying schemes, one of which is through Government Securities (SBN) and Sharia (SBSN).

The concept of distribution policy in Islam upholds justice, therefore this policy is not allowed to side with one particular agent but involves all elements(Noor 2012). This is in line with the meaning of democracy in Indonesia. As long as the policy in running infrastructure involves various parties, the policy is in line with the values that are glorified in Islam, one of which is justice. However, the factual income disparity shows that the owner of large capital in Indonesia is 1:10, in this condition the regulation of the government's side of the grassroots community and in general must be formulated seriously. However the foreign investment has been confirmed there is no implication in income disparity (Hardanto, Ismail, and Khusaini 2017).

In the end, the distribution of public welfare is the ultimate goal of the country which must be fought for in a sustainable manner (Almizan 2016). Therefore the policy of the National Strategic Project (PSN) through infrastructure financed with various schemes established by the government must be based on a holistic and comprehensive view. Economic distribution aimed at equitable access, income and connectivity is important for Indonesia's future development. Then, with the joining of Indonesia with multilateral cooperation, BRI must also maintain and enhance the role of local communities and be accompanied by policies that develop the domestic industry. This is done so that Indonesia is not only an exporter of raw materials but also an exporter of manufactured goods to other countries. In the consequence, the Islamic distribution highly correlated with the production activities which obligated the company not only for profit purposes but also obligated to comply the Islamic teaching (Hardi 2020). So that the infrastructure policy can simultaneously benefit the economy of the domestic community and establish good diplomatic relations with other countries and bring up the country welfare. 


\section{CONCLUSION}

The problem of poverty is still the concentration of the Indonesian government today. In order to reduce the poverty rate, the Indonesian government has formulated policies that focus on infrastructure development. Through the 2018 Committee for the Acceleration of Priority Infrastructure Provision (KPPIP), the number of National Prirotas Projects (PSN) is 37 projects divided into 7 sectors. The investment value required in the framework of implementing this policy reaches IDR 2,428.146 trillion, and at the same time Indonesia experiences a budget deficit of IDR 296.0 trillion in 2019. Thus the Indonesian government is unlikely to finance the project without the help of other parties. One of the alternatives adopted by the Indonesian government is to sign a Memorandum of Understanding (MoU) with China as the initiator of the Belt and Road Initiative (BRI) in the form of multilateral cooperation. The signing of the MoU includes 23 projects from 37 PSNs with an investment value of USD 91.1 billion or Rp 1,275.4 trillion. Therefore, in the short term, the Indonesian government wants it or not to implement this scheme because of the budget deficit and stagnant domestic economic growth.

This article saw that the government's decision to join BRI which was initiated by China is a form of accelerated infrastructure development and when viewed from the distribution paradigm in an Islamic economy in line with Islamic principles. Among these principles are policies that are oriented towards equal access for the wider community which leads to increased income, reduction of economic disparity, and increased economic growth. Although some of these policies do not have a direct correlation to the grass root community, for example, Toll roads will have long-term implications for the welfare of the community. Then, the BRI initiation departed from the hope of regional connection and integration to facilitate the flow of global views. At the same time the over capacity of China's domestic production and the need for raw materials are points that must be considered. Indonesia will become the largest raw material exporter country if this project is not based on policies that are oriented towards industrial defense in Indonesia. On the other hand, policies that do not strengthen domestic equity and exploitation of natural resources will contradict the principle of justice in Islamic distribution.

\section{REFERENCES}

Adhi Bagaskara. 2019. "Ekspansi Proyek OBOR Cina, Indonesia Diminta Waspadai Jebakan Utang." Https://Tirto.Id.

Ali Sakti. 2007. Ekonomi Islam: Jawaban Atan Kekacauan Ekonomi Modern. Jakarta: Paradigma dan Aqsa Publishing.

Almizan. 2016. "Distribusi Pendapatan: Kesejahteraan Menurut Konsep Ekonomi Islam.” Maqdis: Jurnal Kajian EKonomi Islam 1(1):63-81. doi: 10.30736/jpim.v3i2.179.

Aprianto, Naerul Edwin Kiky. 2016. "Kebijakan Distribusi Dalam Pembangunan Ekonomi Islam." Al-Amwal 8(2):491-508.

Ayub, Muhammad. 2007. Understanding Islamic Finance. England: John Wiley \& Sons, Ltd.

Badan Pusat Statistik. 2018a. Indeks Pembangunan Manusia (IPM) Tahun 2018. Jakarta.

Badan Pusat Statistik. 2018b. Profil Kemiskinan Indonesia Maret 2018. Jakarta. 
Badan Pusat Statistik. 2019. Keadaan Ketenagakerjaan Indonesia Februari 2019. Jakarta.

BPJT. 2018. “Kebijakan Percepatan Pembangunan.” Https://Www.Bpjt.Pu.Go.Id.

Chen, Huiping. 2016. "China's 'One Belt, One Road' Initiative and Its Implications for Sino-African Investment Relations." Transnational Corporations Review 08(03):178-82. doi: 10.1080/19186444.2016.1233722.

Du, Julan, and Yifei Zhang. 2018. "Does One Belt One Road Initiative Promote Chinese Oversoas Direct Investment." China Economic Review 47(February):189-205. doi: 10.1016/j.chieco.2017.05.010.

Emamzadeh, Mohammad Reza Alizadeh. 2020. "Analysis of Economic Convergence of Islamic Justice in Selected Islamic Countries." Journal of Economic Structures 9(1):1-10.

Hardanto, H., M. Ismail, and M. Khusaini. 2017. "Analysis of the Effects of Economic Growth, Investment, Regional Taxes, and Capital Expenditure Toward the Income Disparity in Indonesia (2007-2013)." Russian Journal of Agricultural and Socio-Economic Sciences 69(9).

Hardi, Eja Armaz. 2020. "Etika Produksi Islami: Maslahah Dan Maksimalisasi Keuntungan.” Jurnal Ekonomi Islam| Islamic Economics Journal 8(1):98-119.

Hasan, Zubair. 2020. "Distributive Justice: Foundation and Measures." Pp. 121-149 in Leading Issues in Islamic Economics and Finance. Springer.

Herrero, Alicia Garcia, and Jianwei Xu. 2017. "China' s Belt and Road Initiative: Can Europe Expect Trade Gains?" China and World Economy 25(6):84-99. doi: 10.1111/cwe.12222.

Huang, Yiping. 2016. "Understanding China's Belt \& Road Initiative: Motivation, Framework and Assessment." China Economic Review 40(2016):314-21. doi: 10.1016/j.chieco.2016.07.007.

Humas Sekretariat Kabinet. 2018. "Pemerintah Umumkan Paket Kebijakan Ke-16." Https://Www.Setkab.Go.Id.

Hurley, John, Scott Morris, and Gailyn Portelance. 2018. Examining the Debt Implications of the Belt and Road Initiative from a Policy Perspective. 121. Washington.

Kemenprin. 2018. "Staristik Industri." Https://Kemenprin.Go.Id.

Kurniawan, Yandry. 2016. "One Belt One Road (OBOR): Agenda Keamanan Liberal Tiongkok?” Politica 7(2):233-54.

Mannan, Muhammad Abdul. 1993. Islamic Economic: Theory and Prantice. Yoyakarta: Dana Bhakti Prima Yasa.

Maryaningsih, Novi, Adhi Purwanto, and Fajar Oktiyanto. 2014. "Pengaruh Infrastruktur Terhadap Pertumbuhan Ekonomi Indonesia." Buletin Ekonomi Moneter Dan Perbankan 17(1):61-97.

Mulyany, Ratna, and Hafas Furqani. 2019. "Sharing Prosperity: Distributive Justice Framework in An Islamic Moral Economy." MADANIA: JURNAL KAJIAN KEISLAMAN 23(2):117-126.

N, Sita. 2018. "Ini 7 Komoditi Besar Ekspor Indonesia." Https:/Goodnewsfromindonesia.Id.

Noor, Ruslan Abdul Ghofur. 2012. "Kebijakan Distribusi Ekonomi Islam Dalam Membangun Keadilan Ekonomi Indonesia." Islamica: Jurnal Studi Keislaman 6(2):316-28. doi: 10.15642/islamica.2012.6.2.316-328. 
Prioritas, Komite Percepatan Penyediaan Infrastruktur. 2018. Laporan KPPIP Semester 2 2018. Jakarta.

Qarad \}a $>$ wi $>$ (al), Yu>suf. 1973. Fiqh Al-Zaka>h. Vol. 2. Beirut: Muassasah alRisa>lah.

Rahim, Shafinah, and Mustafa Omar Mohammed. 2018. "Operationalizing Distributive Justice from the Perspective of Islamic Economics." International Journal of Economics, Management and Accounting 26(2):415-442.

Rahman, Hendra Yulia. 2019. "Kebijakan Pemerintah Terhadap Belt And Road Initiative (BRI) Dalam Paradigma Ekonomi Syariah." Al-Amwal : Jurnal Ekonomi Dan Perbankan Syari'ah 11(2):173-90. doi: 10.24235/amwal.v11i2.4537.

Ramadhan, Iqbal. 2018. "China's Belt Road Initiative: Dalam Pandangan Teori Geopolitik Klasik." Intermestic: Journal of International Studies 2(2):139-55. doi: 10.24198/intermestic.v2n2.3.

Republik Indonesia. 2015. Rencana Pembangunan Jangka Menengah Nasional (RPJM) 2015-2019. Indonesia: Republik Indonesia.

Schwab, Klaus. 2018. The Global Competitiveness Report 2018. Geneva.

Sulistiani, Siska Lis. 2017. "Distribusi Dalam Ekonomi Islam Untuk Pembangunan Negara Menurut Baqir Ash-Shadr Dan M Abdul Mannan.” Amwaluna 1(1):13349.

Suryawati, Chriswardani. 2005. "Memahami Kemiskinan Secara Multidimensional." 08(03):121-29.

Tinni, ST Khadijah. 2014. "Kepentingan Indonesia Bergabung Dalam AsianInfrastructure Investment Bank (AIIB)." 1-18.

Wang, Yong. 2016. "Offensive for Oefensive: The Belt and Road Initiative and China's New Grand Strategy." The Pacific Review 2748(March). doi: 10.1080/09512748.2016.1154690.

Weiss, Martin A. 2017. Asian Infrastructure Investment Bank ( AIIB ). R44754. United Sates.

Yu, Hong. 2017. 'Motivation behind China's 'One Belt, One Road' Initiatives and Establishment of the Asian Infrastructure Investment Bank." Journal of Contemporary China 26(105):353-68. doi: 10.1080/10670564.2016.1245894.

Yusuf al-Qardhawi. 1973. Fiqh Az-Zakah. Cet-2. Bairut: Muassasah al-Risalah. 